\title{
Evaluation of Some Biological Aspects of the Presence of Abrasive Silica and Thickening Silica in Basic Formulations of Dentifrices
}

\author{
Evaluación de Algunos Aspectos Biológicos de la Presencia de Sílice Abrasivo \\ y Sílice Espesante en Formulaciones Básicas de Dentífricos
}

Vinícius Pedrazzi; José Orestes Del Ciampo; Cássio do Nascimento \& João Paulo Mardegan Issa

PEDRAZZI, V.; DEL CIAMPO, J. O.; DO NASCIMENTO, C. \& ISSA, J. P. M. Evaluation of some biological aspects of the presence of abrasive silica thickening silica in basic formulations of dentifrices.Int. J. Morphol., 27(1):159-168, 2009.

SUMMARY: The aim of this study was to evaluate some biological characteristics and toxicity of basic formulations of dentifrices containing such substances, and to compare them with two existing products in market which also contains silic in their formulations. In this way, it was evaluated some biological parameters: weight of the animals, oral toxicity, hematological parameters, urinary analysis, and histological evaluation. The thrombocytes were also statistically at normal levels. The glutamate-pyruvate transaminase (TGP) showed normal aspect in 5 of the tested groups, as in control. Meanwhile, the oxalacetic transaminase (AST) in one group had a small increase in the control group. Regarding urine, in exception the rats of one group, the rats of the 4 other experimental groups showed leukocytosis urinary statistically higher than the control group. The histological evaluation of the animals showed that specimens from liver, stomach, kidney and submandibular gland presented normal aspects for these organs, without significant characteristics related to inflammatory infiltrates in any of the 6 samples tested in their respective groups.

KEY WORDS: Silica; Dentifrices; Histology; Wistar rats.

\section{INTRODUCTION}

At the present stage of knowledge and development, dentifrices are focused on mechanical plaque removal, alteration of their microbiological constitution, inhibiting the tartar storage, promotion of antiseptic action against specific microorganisms, and other specific functions in different age groups, including desensitizing action (Newbrun, 1988; Thylstrup \& Fejeskov, 1988; Pacios et al., 2003).

With the rapid development of new dental materials, it is essential to carry out preliminary tests to screen and characterize the potentially harmful effects of a material to oral tissues before it is used clinically. There is therefore a great concern about the implications of such biological materials in dentistry, including with regard to cosmetics (Sherrill \& Krouse, 1986; Roberta et al., 2003; Andreou et al., 2007; Cerqueira et al., 2008), as the inclusion of abrasive particles insoluble, chemical-therapeutic agents and enzymes that have suggested to the Council on Dental
Therapeutics "The American Dental Association" to establish rules for the acceptance of these products (Sherrill $\&$ Krouse).

The clinical relevance of tests for the assessment of cytotoxicity of dental materials is widely recognized. Many in vivo studies have been pointed out about the problems related to tooth paste absorption by kids (Simard et al., 1991; Naccache et al., 1992; Roberta et al.), especially in relation to the tooth pastes that have fluoride compounds. Different assays and different cell types cultured in vitro have been used to test dental materials. Cytotoxic effects on the cells have been found from changes in cell morphology, from a slower replication rate for cells which were damaged but not killed, from neutral red uptake for cell viability, from propidium iodide staining for cell death, and amide black staining for cell growth, as well as from survival rate (Geurtsen et al., 1998; Chen et al., 2002). 
Considering the problem of dentifrices swallowing by hospitalized patients, who could reach death due to respiratory complications resulting from the swallowing of sparkling, Morrow et al. (1972) developed a tooth paste without foam.

Considering the growing application of silic products in oral hygiene products with different purposes, this work aims to evaluate some biological characteristics and toxicity of basic formulations of dentifrices containing such substances, and has as objective to compare them with two existing products in market and which also contains silic in their formulations.

\section{MATERIAL AND METHOD}

Biological tests. For the verification of possible adverse effects of silic components in dentifrices, with thickness and abrasive purposes, it was made preparations containing some of these products, related only to water, glycerin and preservative to obtain results that are very specific. It was used a control solution (sodium chloride to $0.9 \%$ ), three preparations made with abrasive silic and/or thickness and two dentifrices available on the market, which also have silic components.

Weight of the animals. It was used in this study Wistar rats weighting initially around $200 \mathrm{~g}$. All the aspects of this work were approved by local ethic committee. The animals, male and female group, were weighed in the beginning, each week of the experiment, and finally in the end of the experiment (28 days).

Oral toxicity evaluation. It was determined the effects of the administered samples by oral administration in rats during 28 days, once a day. The water and chow were gave ad libitum for the animals and removed 4 hours before the samples administration, and gave again after each administration. It was used 6 groups with 12 animals each, composed by 6 male and 6 female animals in each group, totalizing 72 rats. As a control solution, it was used sodium chloride at $0.9 \%$ - Group 1. Group 2 received a preparation of Tixosil 73 (abrasive silic) and Tixosil 333 (thickener silic). Group 3 received the preparation of Tixosil 73 (abrasive silic). Group 4 received a preparation of Tixosil 73 (abrasive silic) and Aerosil 200 (thickener silic). Groups 5 and 6 were composed by commercial preparations, Group 5 received a dilution of toothpaste Emoform Anti-Plaque, and Group 6 received a dilution of toothpaste Emoform Anti-Tatar. All experimental dentifrices have their laboratory performance evaluated previously, regarding physical and physical-chemical aspects and they were also compared with the commercial dentifrices (Pedrazzi et al., 1999a; Pedrazzi et al., 1999b).
The preparations of groups 1 and 3 were directly administered to the rats, $0.5 \mathrm{~mL} / \mathrm{animal}$. Meanwhile, the viscosity of other preparations required dilution in water, diluting them with water in equal proportions with the aim to administrate by the oral cavity in the animals. Due to this dilution, it was administered $1.0 \mathrm{~mL}$ of this suspension daily. This procedure was also used for preparations administered to the groups 5 and 6 .

The suspensions were administered during 28 days, after which the urine and blood of animals were collected. The urine collection began in the day of the test (day 28), and the urine labeled and sent together with blood samples to a laboratory for medical tests. The blood collection occurred in the day 29 of the study, day of sacrifice, when the animals were anesthetized with ether sulfuric inhaled. An inferior cut was made in the abdominal cavity with the aim to expose the inferior vena cava, and aspirate 4 to $6 \mathrm{~mL}$ of blood. The collected blood was deposited on 2 separate bottles and identified for each animal, one of these vials contained heparin in the internal walls (for transaminases evaluation) and the other not (for complete blood counting). The material was identified and sent to the Laboratory of Clinical Analysis for the following evaluations below.

Hematological evaluation. Red series: Red cells, hemoglobin, haematocrit, middle globular volume (VGM), average globular hemoglobin (HGM), average concentration of globular hemoglobinic (CHGM);

White series: leukocytes, neutrophils, eosinophils, basophils, monocytes, lymphocytes;

Platelets: the number of thrombocytes. It was also evaluated the oxalacetic transaminase (AST) and piruvic (TGP).

\section{Urinary analysis.}

Physical examination: volume, $\mathrm{pH}$ and density.

Chemical review: ketone bodies.

Examination of microscopic sediments: leukocytes, erythrocytes.

Histological evaluation. The animals were sacrificed and, through conventional methods, samples were taken from tissues of organs selected for the study (liver, stomach, kidneys, and submandibular gland). The samples were fixed during 24 hours in 4\% PFA and performed the histological techniques, being carried out serial histological cuts $7 \mu \mathrm{m}$ of thick that were subsequently stained by hematoxylin-eosin. The histological fields were captured in 60 and 200X of magnification with the aid of an optical photomicroscope Nikon Alphaphot-2 (YS2). Due to the infusion solution, it was not considered the weight of the organs in this phase. 
Statistical analysis. The present data did not present a normal distribution, in this way, it was used the non-parametric test, Wilcoxon rank sun test with $95 \%$ of confidence level.

\section{RESULTS}

Body weight analysis. When contrasted to the Group I (control), considering the five experimental groups only the Group IV showed statistical difference in relation to the weight gain $(\mathrm{p}<0.05)$, both for male and female rats (Table I).

Hematological analysis, Red Series. When compared to the Group I, considering the erythrocytes parameter for the five experimental groups, only the Group II presented statistical significant $(\mathrm{p}<0.05)$. According to hemoglobin parameter, only the Group II showed significant difference $(\mathrm{p}<0.05)$. For the following parameters, hematocrit, VGM and HGM, it was not found significant difference $(\mathrm{p}>0.05)$ for any of the experimental groups when contrasted to the Group I (control). For the CHGM parameter, groups IV, V and VI showed statistical significance $(\mathrm{p}<0.05)$ (Table II).

Hematological analysis: White series. Analyzing the leukocytes parameter, the Group III was the only one that when contrasted to the Group I (control) showed significant alteration $(\mathrm{p}<0.05)$. Also, for the neutrophils parameter, Group III was the only that presented statistical difference $(\mathrm{p}<0.05)$. For eosinophils parameter, none of the groups compared to the

Table I. Weight variation according to the time.

\begin{tabular}{llcllll}
\hline & & & \multicolumn{2}{c}{ Weight of the animals $(\mathrm{g})$} & & \\
Group & Gender & Initial weight & at 1 week & at 2 weeks & final & difference \\
\hline I & M & 202.83 & 252.83 & 290 & 314.83 & 112 \\
I & F & 190.83 & 230.66 & 228.33 & 247.83 & 57 \\
II & M & 190.5 & 240.5 & 311 & 332.16 & 141.66 \\
II & F & 191.66 & 205.5 & 224.5 & 223.33 & 51.33 \\
III & M & 187.16 & 251.5 & 284.66 & 326.33 & 139.16 \\
III & F & 215.5 & 238.33 & 257.83 & 281.5 & 66 \\
IV & M & 186.83 & 231.5 & 300.83 & 340.33 & 153.5 \\
IV & F & 183.66 & 186.33 & 237.66 & 271.5 & 87.83 \\
V & M & 222.66 & 301.5 & 319.66 & 342.33 & 119.66 \\
V & F & 194.83 & 218.5 & 221.16 & 229 & 32.66 \\
VI & M & 194.66 & 213.5 & 283.66 & 322.5 & 127.83 \\
VI & F & 212.33 & 224.83 & 248.33 & 262.5 & 50.16 \\
\hline
\end{tabular}

Table II. Hematological evaluation: Red series according to groups and genders

\begin{tabular}{|c|c|c|c|c|c|c|c|}
\hline \multirow[t]{2}{*}{ Group } & Gender & Erythrocytes & Hemoglobin & Hematocrit & VGM & HGM & CHGM \\
\hline & & $8.9 \mathrm{~m} / \mathrm{mm}^{3 \#}$ & $14.8 \mathrm{~g} / 100 \mathrm{ml}^{\#}$ & $46 \% \#$ & $61 \mathrm{fl} \#$ & $18.9 \mathrm{pg}^{\#}$ & $32 \mathrm{~g} / \mathrm{dl}^{\#}$ \\
\hline I & M & 8.33 & 16.23 & 50.00 & 59.83 & 19.5 & 32.33 \\
\hline I & $\mathrm{F}$ & 7.13 & 13.15 & 42.66 & 59.83 & 18.33 & 30.66 \\
\hline II & M & 8.61 & 16.66 & 51.00 & 59.00 & 19.50 & 32.83 \\
\hline II & F & 8.69 & 16.85 & 50.33 & 57.66 & 19.50 & 33.66 \\
\hline III & M & 7.85 & 15.30 & 46.66 & 59.16 & 19.50 & 32.83 \\
\hline III & $\mathrm{F}$ & 7.88 & 15.31 & 46.33 & 58.66 & 19.33 & 32.83 \\
\hline IV & M & 7.85 & 16.41 & 46.83 & 60.16 & 20.83 & 35.00 \\
\hline IV & F & 7.45 & 15.63 & 45.00 & 59.00 & 20.33 & 34.66 \\
\hline V & M & 8.38 & 16.20 & 48.66 & 58.00 & 19.16 & 33.33 \\
\hline $\mathrm{V}$ & $\mathrm{F}$ & 7.66 & 14.93 & 44.00 & 57.66 & 19.33 & 34.00 \\
\hline VI & M & 8.08 & 16.43 & 49.50 & 61.33 & 20.33 & 33.33 \\
\hline VI & $\mathrm{F}$ & 8.03 & 15.81 & 45.16 & 56.00 & 19.66 & 35.16 \\
\hline
\end{tabular}


Group I (control) showed statistical significance ( $\mathrm{p}>0.05)$. According to monocytes evaluation, Group II showed significant alteration $(\mathrm{p}<0.05)$ compared to the control. For lymphocytes parameter, none of the groups showed statistical difference ( $p>0.05$ ) compared to the Group I (control) (Table III).

Transaminases and platelets analysis. None of the platelets and pyruvate transaminase glutamate (TGP) parameters, considering the 5 experimental groups, had statistically significant differences ( $\mathrm{p}>0.05)$ when contrasted to the Group I (control). Moreover, the transaminase oxalacetic (AST) parameter presented in the Group III showed statistical differences $(\mathrm{p}<0.05)$ (Table IV).

Urinary Evaluation. It was found significant differences
( $p<0.05$ ) between the Group IV and Group I (control), where the excreted volume of urine by rats of the Group IV was statistically higher than the rats of the Group I, and between the Group VI and Group I (control), where the urine excreted volume by rats of the Group VI was lower than the rats of the Group I, meaning that there was greater volume of urine excreted by rats in groups following the order IV>I $>V I$. Evaluating the $\mathrm{pH}$ parameter, only the Group VI showed statistical significant differences $(\mathrm{p}<0.05)$ in relation to the Group I (control), since the urine of the rats of the Group VI presented the highest $\mathrm{pH}$, or alkaline, when would be the normal acid or slightly acid.

When the density parameter was evaluated, only the Group V showed statistical difference $(\mathrm{p}<0.05)$. Considering

Table III. Hematological evaluation - white series according to groups and genders

\begin{tabular}{llccccc}
\hline Group & Gender & Leukocytes & Neutrophils & Eosinophils & Monocytes & Lymphocytes \\
& & 9.421 & $1.786(8-25 \%)$ & $273(0-500)$ & $139(270)$ & 7.209 \\
\hline I & M & 7.15 & $154.13(21.4 \%)$ & 140 & 286.83 & $4.31(74 \%)$ \\
I & F & 8.1 & $1.43(18.16 \%)$ & 95.16 & 291.66 & $6.28(76.66 \%)$ \\
II & M & 11.06 & $3.28(29.16 \%)$ & 149.66 & 579.33 & $6.96(63.83 \%)$ \\
II & F & 7.35 & $134.83(26.83 \%)$ & 94.5 & 378.33 & $4.89(66.5 \%)$ \\
III & M & 14.7 & $3.80(25.66 \%)$ & 228.5 & 567.16 & $9.86(67.5 \%)$ \\
III & F & 10.35 & $158.41(21.83 \%)$ & 114.83 & 309.66 & $7.54(73 \%)$ \\
IV & M & 11.03 & $3.17(27.83 \%)$ & 110.33 & 335 & $7.33(67.66 \%)$ \\
IV & F & 6.14 & $351.69(18.83 \%)$ & 69.16 & 248.66 & $4.58(75.33 \%)$ \\
V & M & 12.78 & $2.49(19.5 \%)$ & 127.83 & 399.66 & $9.69(75.83 \%)$ \\
V & F & 7.13 & $147.33(24.83 \%)$ & 141.66 & 167.33 & $4.96(70.16 \%)$ \\
VI & M & 13.6 & $2.79(19.83 \%)$ & 113.66 & 393.5 & $10.16(75.5 \%)$ \\
VI & F & 7.88 & $289.14(19.83 \%)$ & 77.83 & 198.16 & $6.01(76.83 \%)$ \\
\hline
\end{tabular}

Table IV. Transaminases and platelets evaluation

\begin{tabular}{ccccc}
\hline Group & Gender & $\begin{array}{c}\text { TGO } \\
(88 \pm 22 \%)\end{array}$ & $\begin{array}{c}\text { TGP } \\
(53 \pm 13 \%)\end{array}$ & $\begin{array}{c}\text { platelets } \\
(754.000)\end{array}$ \\
\hline I & M & 143.83 & 39.83 & 708.8 \\
I & F & 178.83 & 34.66 & 788.0 \\
II & M & 189.5 & 55.66 & 690.5 \\
II & F & 163.83 & 45.16 & 859.5 \\
III & M & 267.01 & 74.66 & 859.0 \\
III & F & 186.5 & 63.66 & 778.33 \\
IV & M & 135.83 & 31.83 & 871.4 \\
IV & F & 127 & 29.66 & 896.0 \\
V & M & 156.16 & 42.33 & 865.66 \\
V & F & 142.5 & 33.83 & 875.0 \\
VI & M & 126 & 41.66 & 887.0 \\
VI & F & 105.16 & 31.16 & 911.66 \\
\hline
\end{tabular}


the leukocytes presence in the urine of the rats from experimental and control groups were not so much according to the applied tests. Group III, IV, V and VI were statistically different $(\mathrm{p}<0.05)$. In the Group I (control), it was found a great presence of leukocytes in urine of the rats, indicating that there was inflammatory process in the urinary tract of the rats of these groups. Only the rats of the Group II (abrasive silica + thickener Tixosil $=73+$ Tixosil 333) did not presented significant differences $(\mathrm{p}>0.05)$ in relation to the rats of the control group. Regarding the presence of red blood cells in the urine of rats, only the Group II showed significant differences $(p<0.05)$ when contrasted to the Group I (con- trol), but the number of red blood cells in the urine of the rats was lower than the rats of the control group, showing that there was no hematuria in any of the tested groups (Table V).

Histological analysis. Under macroscopic examination, the removed organs showed normal aspect, without morphological changes. The samples composed by liver, stomach, kidney and submandibular gland stained by hematoxylin-eosin revealed that all of them had histological characteristics compatible to normal structures, without inflammatory cell infiltration, which indicate the existence of anomalies in these structures (Fig.1).

Table V. Urinary evaluation.

\begin{tabular}{cccccccc}
\hline Group & Gender & Volume $(\mathrm{mL})$ & $\mathrm{pH}$ & Density & Ketone bodies & Leukocytes & Erythrocytes \\
\hline I & M & 8.5 & 6.66 & 1025.16 & 0 & 0.16 & 4.16 \\
I & F & 7.66 & 7.05 & 1024.33 & 0 & 0.00 & 0.16 \\
II & M & 13.83 & 7.83 & 1038.33 & 0 & 0.28 & 0.26 \\
II & F & 10.66 & 6.83 & 1036.33 & 0 & 0.24 & 0.24 \\
III & M & 13.33 & 7.16 & 1026.66 & 0 & 0.65 & 2.20 \\
III & F & 9.0 & 7.50 & 1034.16 & 0 & 1.40 & 1.47 \\
IV & M & 13.5 & 6.66 & 1035.33 & 0 & 1.75 & 2.11 \\
IV & F & 14.66 & 6.50 & 1022.66 & 0 & 2.22 & 2.38 \\
V & M & 4.83 & 8.00 & 1050.33 & 0 & 0.56 & 0.90 \\
V & F & 4.66 & 6.66 & 1054.16 & 0 & 0.34 & 1.54 \\
VI & M & 4.0 & 8.50 & 1021.16 & 0 & 0.51 & 0.66 \\
VI & F & 3.0 & 8.66 & 1035.00 & 0 & 0.39 & 1.62 \\
\hline
\end{tabular}
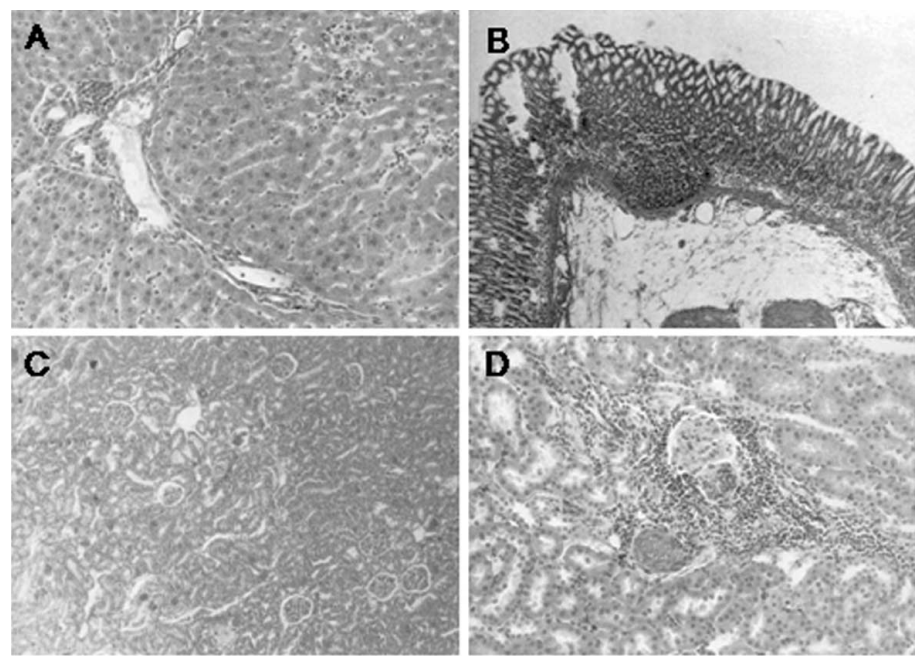

Fig. 1A. Photomicrography showing a liver lobe and the hepatic portal system with normal aspect. H-E. (200 x).

Fig. 1B. Cross section of the stomach walls showing the smooth muscle cells, glands, lymphoid and connective tissue highly vascularized, commonly situation found in rats with normal aspect. H-E. $(60 \mathrm{x})$.

Fig. 1C. Section of the kidney cortex showing clusters, Bowman capsules, proximal and distal sinuous tubules with normal aspect. H-E. $(60 \mathrm{x})$.

Fig. 1D. Kidney clusters with vessels, tubular structures and connective tissue with normal aspect. H-E. (200 x).

Fig. 1E. Crossection of submandibular gland belong to a normal rat, showing the salivary ducts, acines, connective tissue and capsules. H-E. (60 x). 


\section{DISCUSSION}

The purpose of this study was to evaluate some biological characteristics and toxicity of basic formulations of dentifrices containing such substances, and compare them to two products in the market and which also contains silica in their formulations. The tested samples in this study follow the Gaffar \& Afflitto, 1992 requirements and other authors who claim compatible systems for therapeutic dentifrices and other dental materials (Cerqueira $e t$ al.) that have not impair or interference in bioavailability and activity of substances with preventive and curative action components of a toothpaste.

In respect to weight variations of the animals, it was found variations in all tested groups. Animals were usually gain weight during the time, situation commonly found in Wistar rats lineage (Snell, 1941; Farris \& Griffith, 1962; Totani et al., 2008). Male animals of the Group I gained on average $54 \%$ of total body weight during the period of 1 month that lasted of the experiment, while Group II gained $75 \%$, the animals of Group III showed on $74 \%$ average of weight gain. The winners belong to Group IV - 82\% (the largest percentage gain medium), the group V showed 54\% of weight gain on average and the Group VI gained $66 \%$. Female rats showed the following average body weight for each group: Group I $=30 \%$, Group II $=27 \%$, Group III $=$ $31 \%$, Group IV $=48 \%$ (weight gain greater percentage of the 6 groups), Group V $=17 \%$ and finally, the Group VI = $24 \%$. The difference of weight gain between male and female was expected, since the female in this age are entering the reproductive phase, with obvious hormonal changes, which brings them less weight gain in proportion (Snell; Farris \& Griffith; Gorski et al., 2006). Statistical analysis for variation of weight gain in animals, separate male and female, the non-parametric Wilcoxon test revealed that only the rats belonged to the Group IV showed significant weight gain, when contrasted to the Group I (control).

Clinical and laboratory reports of blood - red series, showed that a mouse of the Group I presented discreet anisocytosis or a change in the diameter of the red blood cells, and policromatophilia, red blood cells with traces of basophilic substances (RNA). When occurs a concomitant increase of policromatophilic with reticulocytes (reticulocytosis), sets up a case of severe regenerative anemia (Petkov, 1994). Two rats showed, as well as sharp anisocytosis and policromatophilia, an anemia that occurs in thalassemia, and the hematocrit of one of the rats was below of the normal status, showing the existence of an anemia. The peripheral blood of the 9 remaining rats in the group did not presented morphological changes. In Group II, all the rats showed blood with normocytic aspect, with the peripheral blood without morphological changes. In Group III, 2 female and 1 male rats showed marked anisocytosis and policromatophilia, while another 2 male and 1 female rats showed discreet anisocytosis and policromatophilia, revealing an anemia condition, especially the last rat that had low haematocrit. The 6 rats had other peripheral blood without morphological changes. In Group IV, 3 male rats and 1 female rat presented policromatophilia in the blood, and 1 female rat presented discrete anisocytosis, with low haematocrit, indicating that it could be in anemic condition. All other rats showed normocytosis without morphological changes. In Group V, the blood of 3 male and 3 female rats had discrete anisocytosis and policromatophilia. One rat had only mild anisocytosis and other female rat presented an anemia condition revealed by the haematocrit. The blood of the other 4 animals was normal, without morphological changes. In Group VI, all the rats showed normocytosis blood and peripheral blood without morphological changes. One male and one female rats showed discreet anisocytosis blood, but with the normal haematocrit. All these description are in according to classical literature of hematology, described here by Harmening (2002).

Moreover, the statistical analysis of blood red examinations, red cells parameter, showed that in the five experimental groups, only the Group II showed a slight increase in the number of these cells, but this fact does not characterize an erythrocytosis condition. In hemoglobin examinations, Group II was also the only group with a significant increase compared to group I, despite this fact does not characterize as erythrocytosis condition. For the haematocrit, VGM, and HGM parameters, none of the experimental groups showed significant changes when contrasted to the group I, which indicates there is not any anemia evidence in the five experimental groups (Harmening). The CHGM parameter what was inside the analysis of blood - red series - presented the largest number of groups contrasting to the group I, with an increase of this hematological index.

According to clinical and laboratory report issued together with the results of blood - white series in Group II, 2 female rats showed leukopenia, but with good proportions in relation to lymphocytic and neutrophilic cells. Two female and 1 male rats showed neutrophilia, which may have a clinical significance of the relevant part of endogenous intoxication. One male rat had lymphocytopenia still acute, which can mean cirrhosis, as it was not absolute. There were 7 rats with normocytosis. In Group III, there was normocytosis in 8 rats. However, there was leukocytosis in 
1 male and 2 female rats, with leukocytosis in the male animal $\left(24.300 / \mathrm{mm}^{3}\right)$, but that the misuse of a leukogram only means that the animal is defensive in the third stage, the lymphocyte, healing from infectious processes. The monocitary and eosinophilic levels confirm this situation. In Group IV, 5 female rats showed a leukopenia situation, more pronounced in one of them, which could provide an acute anemia, allergy or poisoning. In a male rat, it was found a table of soft lymphocytopenia without clinical significance. The other group of rats presented normocytosis. In Group V, only 3 male rats showed mild leukocytosis, and 1 female rat presented mild leukopenia, without clinical significance, the others showed normocytosis. It was found leukocytosis in 4 male rats, maybe associated to an infectious process recovering; mild leukopenia was observed in 1 female rat, but without clinical significance in the rats of the Group VI.

In the evaluation of the white blood series, the results indicated that the Group III was the only one who presented an increase in the number of these cells (mild leukocytosis and neutrophilia) statistically significant when contrasted to the Group I, but discrete enough to show the importance of this fact. The eosinophil parameters and lymphocytes (important for diagnosis of infections and malignancies) were not statistically significant in any of the five experimental groups when contrasted to the Group I. For monocytes' level, Group II was the only one that when contrasted to the Group I, presented statistical significance, but on a small scale, the maximum that could indicate the presence of a protozoans in animals of that group.

The clinical and laboratory reports issued together with biochemical analysis of the blood (oxalacetic transaminase and glutamate-pyruvate) and trombocitary series, in Group I, only 1 female rat presented small change in the rate of transaminase glutamate-oxaloacetic (AST), but it could mean only a liver poisoning, according to data from crossing with the leukogram. The platelets were at normal levels, according to medical reports. The rats of both genders in Group II showed regular levels of transaminase and thrombocytes. In Group III, there were two cases of TGO significant increases. A male rat, with $709 \mathrm{u}$ of level, probably was part of hepatic necrosis less serious than 1 level of male rats with $1095 \mathrm{u}$, which may indicate serious virotic hepatitis. It may have occurred liver obstruction and kidney problems in rats at higher levels, however, the findings in leukogram of these rats are not conclusive to speculate about these pathologies. Concerning the thrombocitary system, the findings are normal. In Group IV, all the rats showed levels of TGO, TGP, and platelets in normal condition. In group V, also all the rats of both genders showed normal levels of thrombocytes and transaminase according to the literature (Snell; Farris \& Griffith; Silva Jr. et al., 1986).
The Group VI showed normal values for transaminases and platelets. In addition, considering the results for transaminase (TGO and TGP) and platelets examinations, the glutamate-pyruvate transaminase (TGP) and platelet series did not have statistical significance when the Group I was compared to any of the five experimental groups. Meanwhile, in relation to oxalacetic transaminase (TGO) parameter, the Group III showed greater values than the Group I (control), despite it was not observed any evidence of serious liver disease.

The clinical and laboratory findings reported little bacteriuria in the urine of the rats in Group I. The rats of the Group II had mostly cloudy urine, which coincides with the reaction to the $\mathrm{pH}$ (a urine newly harvested when it is translucent and crystalline acid, but cloudy when at rest and alkaline). The rats of this group had degrees of intense bacteriuria, which coincides with the findings of neutrophilia in leukogram. The rats of Group III had cloudy urine, with the presence of red blood cells and / or hemoglobin in the urine of 5 male rats and 4 female rats, indicating a possible hematuria condition, which could suggest glomerulonephritis, cystitis or leukemia. However these figures were not sustained by those found in leukogram. In Group IV, the presence of many white blood cells and red blood cells in the urine of rats, as well as intense bacteriuria could strengthen the hypothesis of an anemia in one of the animals. Animals of the Group V showed moderate degrees of bacteriuria and the presence of ketone bodies in 5 rats, paying attention about the glucose metabolism deficiency provoking the acetone accumulation in the liver, forming "ketone bodies" (Havel \& Weuster-Botz 2007; Quijano et al., 2007), characteristic of diabetes condition and starvation, which could explain the low gains in weight of the rats of this group. In Group VI, it was found amorphous calcium phosphate in the urine of all the rats, without however, a meaningless diagnosis.

The Wilcoxon analysis applied to the urine examination showed for the urine volume parameter that the volume excreted by the rats of the Group IV was statistically greater than that excreted by the rats of the Group I, while the volume excreted by the rats of the Group VI was statistically lower than the rats of the Group I, but without any physiological changes and / or pathological evidence. Analysis of the urine density showed for the Group V that this parameter was statistically higher than the Group I, but as density and volume are correlated, it was not found clinical significance.

In relation to urinary $\mathrm{pH}$, only the Group VI presented statistical significance when contrasted to the group I, showing a $\mathrm{pH}$ average higher than the control group, which means that the urine of the rats in that group showed alkaline characteristics, when it should be acid. This fact could easily 
be explained by assuming that this sample probably contains specific agents in it. In relation to the leukocytes presence in urine of the rats, contrasting the five experimental groups to the Group I that received the first sample, it was found more groups with statistical differences, indicating that the urinary tract of the rats of these groups had inflammatory process. Only the Group II did not have differences in this parameter when contrasted to the group I. According to red blood cells presence in urine, only the group II showed red blood cells in urine excreted statistically lower than the rats of the Group I, indicating that the urinary tract of these rats presented inflammatory processes.

In relation to the histological evaluation of the liver, stomach, kidney and submandibular gland, the analysis showed that all the samples had characteristics compatible to normal aspects for each organ, in the Group I and other groups, according to the literature (Costa \& Chaves, 1949; Bailey et al., 1973; Leeson et al., 1985). A few cases of inflammatory infiltration observed in some tissues were considered normal. Hannon et al. (1983), studied cases of foreign body due to silica developed in the oral cavity of patients after traumatic deployment of sand, in this way, we should consider the possibility of such injuries occur by swallowing products during teeth brushing with dentifrices containing silica in their formulations, until the introduction of silica particles in gingival sulcus. While some changes have been found in biochemical tests, these situations can conduce to the possible existence of pathological processes that should be considered as isolated cases and should not be worrying because they are lighter and are also present in Group I.
It was possible to conclude that in respect to the changes in body weight of rats during 29 days of this experimental research, only the rats of the Group IV received a statistically significant weight gain for both genders.

The blood of the rats showed no changes in the parameters that could be evaluated conclusive, in clinical terms, an anemia situation or change in crase blood, and in none of the 5 leukogram samples tested provoked reactions indicative of infectious processes in any of 5 groups' products, such as the control group. The thrombocytes were also statistically at normal levels. The glutamate-pyruvate transaminase (TGP) showed normal aspect in 5 of the tested groups, as in control. Meanwhile, the oxalacetic transaminase (AST) in Group III had a small increase in the control group, but with the point of low figures are not indicative of having been cirrhosis, or liver obstruction in rats of this group. Regarding urine, in exception the rats of Group II, the rats of the 4 other experimental groups showed leukocytosis urinary statistically higher than the control group, which is indicative of inflammation occurrence in the urinary tract of the animals of these groups.

The histological evaluation of the animals showed that specimens from liver, stomach, kidney and submandibular gland presented normal aspects for these organs, without significant characteristics related to inflammatory infiltrates or mutagenicity in any of the 6 samples tested in their respective groups. Grossly the esophagus and the inner wall of the stomach did not show scars or abnormalities that indicate the introduction of the hypodermic tube with the tip active modified, used to track gold-gastric inoculation of the samples tested.

PEDRAZZI, V.; DEL CIAMPO, J. O.; DO NASCIMENTO, C. \& ISSA, J. P. M. Evaluación de algunos aspectos biológicos de la presencia de sílice abrasivo y sílice espesante en formulaciones básicas de dentífricos. .Int. J. Morphol., 27(1):159-168, 2009.

RESUMEN: El objetivo del estudio fue evaluar algunas características biológicas y de toxicidad provenientes de las formulaciones básicas de dentífricos que contienen sílice en su composición y compararlos con dos dentífricos disponibles comercialmente que también presentan sílice. El análisis hematológico no mostró diferencias entre los grupos evaluados. Los niveles de trombocitos presentados por los grupos fueron también normales. La transaminasa gluámico pirúbica se mostró un aspecto normal en 5 de los grupos estudiados, así como en el grupo control. La transaminasa glutámico oxaloacética en uno de los grupos tuvo un pequeño incremento. En relación a la orina, 4 grupos presentaron leucocitosis urinaria significativamente mayor que el grupo de control. La evaluación histológica del hígado, estómago, riñones y glándulas submandibulares se presentó con aspecto normal, sin presencia de infiltrado inflamatorio.

PALABRAS CLAVE: Sílice; Dentífrico; Histología; Ratones Wistar.

\section{REFERENCES}

Andreou, A.; Dabarakis, N.; Kagiava, A.; Kosmidis, E.K.; Geronikaki, A. \& Theophilidis, G. Assessing the effects of three dental impression materials on the isolated sciatic nerve of rat and frog. Toxicol. in Vitro, 21(1):103-8, 2007.
Bailey, F. R.; Copenhaver, W. M. \& Bunge, R. P. Histologia. São Paulo-SP, Edgard Blücher, 1973.

Cerqueira, D. F.; Mello-Moura, A. C.; Santos, E. M. \& Guedes-Pinto, A.C. Cytotoxicity, histopathological, 
microbiological and clinical aspects of an endodontic iodoform-based paste used in pediatric dentistry: A review. J. Clin. Pediatr. Dent., 32(2):105-10, 2008.

Chen, S. Y.; Chen, C. C. \& Kuo, H. W. Cytotoxicity of dental impression materials. Bull. Environ. Contam. Toxicol. 69(3):350-5, 2002.

Costa, A. C. \& Chaves, P. R. Tratado Elemental de Histología y Anatomía Microscópica. $2^{\mathrm{a}}$ ed. Lisboa, Livraria LusoEspanhola, 1949.

Farris, E. J. \& Griffith, J. Q. The rat in laboratory investigation. $2^{\text {nd }}$ ed. New York, Hafner Publishing, 1962.

Gaffar, A. \& Afflitto, J. General principles for the delivery of active agents from mouthrinses. Int. Dent. J., 42(4S1):253-62, 1992.

Geurtsen W.; Lehmann F.; Spahl W. \& Leyhausen G. Cytotoxicity of 35 dental resin composite monomers/ additives in permanent $3 \mathrm{~T} 3$ and three human primary fibroblasts cultures. J. Biomed. Mater. Res., 41(3):47480, 1998.

Gorski, J. N.; Dunn-Meynell, A. A.; Hartman, T. G. \& Levin, B. E. Postnatal environment overrides genetic and prenatal factors influencing offspring obesity and insulin resistance. Am. J. Physiol. Regul. Integr. Comp. Physiol., 291(3):768-78, 2006.

Hannon, S. M.; Pickett, A. B. \& Frost, J. M. Foreign-body (silica) granuloma of the lip. J. Oral. Maxillofac. Surg., 41(7): 470-2, 1983.

Harmening, D. M. Clinical Hematology and Fundamentals of Hemostasis. $4^{\text {th }}$ ed. Philadelphia, Pennsylvania, F. A. Davis Publishing Company, 2002.

Havel, J. \& Weuster-Botz, D. Cofactor regeneration in phototrophic cyanobacteria applied for asymmetric reduction of ketones. Appl. Microbiol. Biotechnol., 75(5):1031-7, 2007.

Leeson, C. R.; Leeson, T. S. \& Paparo, A. A. Textbook of Histology. $5^{\text {th }}$ ed. Philadelphia. W. B Saunders Company, 1985.

Morrow, J. A.; Wightman, J. R.; Shannon, I. L. \& Miller, J. $\mathrm{T}$. The use of an ingestible dentifrice in a hospital population. J. Hosp. Dent. Pract., 6(1):27-30, 1972.

Naccache, H.; Simard, P. L.; Trahan, L.; Brodeur, J.; Demers,
M.; Lachapelle, D. \& Bernard, P.M. Factors affecting the ingestion of fluoride dentifrice by children. J. Public Health Dent., 52(4):222-6, 1992.

Newbrun, E. Cariologia. São Paulo. Livraria Editora Santos, 1988.

Pacios, M.G.; de la Casa, M.L.; de los Angeles Bulacio, M. \& López, M.E. Calcium hydroxide's association with different vehicles: In vitro action on some dentinal components. Oral Surg. Oral Med. Oral Pathol. Oral Radiol. Endod., 96(1):96-101, 2003.

Pedrazzi, V.; Lara, E. H. G. \& Panzeri, H. Sílica em dentifrícios: Aspectos físicos e físico-químicos. Cosmetics \& Toiletries, 11:66-9, 1999a.

Pedrazzi, V.; Lara, E. H. G.; Panzeri, H. \& Ogasawara, M. S. Análisis estereológico de fórmulas básicas de dentifrícios conteniendo sílice abrasiva y sílice espesante. Rev. Fola. Oral., 5(15):46-51, 1999b.

Petkov, I. The morphological characteristics of the circulating blood after massive reinfusion in operative surgery. Khirurgiia, 47(3):31-5, 1994.

Quijano, C.; Castro, L.; Peluffo, G.; Valez, V. \& Radi, R. Enhanced mitochondrial superoxide in hyperglycemic endothelial cells: Direct measurements and formation of hydrogen peroxide and peroxynitrite. Am. J. Physiol. Heart Circ. Physiol., 293:3404-14, 2007.

Roberta, T.; Federico, M.; Federica, B.; Antonietta, C. M.; Sergio, B. \& Ugo, C. Study of the potential cytotoxicity of dental impression materials. Toxicol. In Vitro, 17(56):657-62, 2003.

Sherrill, C. A. \& Krouse, M. A critical look at recent dentifrice claims. Dent. Hyg. (Chic.), 60(9):410-7, 1986.

Silva Jr., O. C.; Franco, C. F. S.; Picinato, M. A. N. C. \& Souza, M. E. J. Modelos experimentais de pesquisa em cirurgia. (Cap. VI) In: Constiuintes bioquímicos e enzimáticos do soro. Silva Jr. O. C. \& Zucoloto, S. Editores. Ribeirão Preto, Robe Editorial, 1986.

Simard, P. L.; Naccache, H.; Lachapelle, D. \& Brodeur, J. M. Ingestion of fluoride from dentifrices by children aged 12 to 24 months. Clin. Pediatr., 30(11):614-7, 1991.

Snell, G. D. Biology of the laboratory mouse. New York, Dover Publications, Inc., 1941. 
PEDRAZZI, V.; DEL CIAMPO, J. O.; DO NASCIMENTO, C. \& ISSA, J. P. M. Evaluation of some biological aspects of the presence of abrasive silica thickening silica in basic formulations of dentifrices.Int. J. Morphol., 27(1):159-168, 2009

Thylstrup, A. \& Fejeskov, O. Tratado de Cariologia. Rio de Janeiro. Editora Cultura Médica Ltda, 1988.

Totani, N.; Burenjargal, M. \& Yawata, M. Effects of oil heated with gluten on weight-loss dieting. I. J. Oleo. Sci., 57(6):321-6, 2008.
Correspondence to:

Prof. Dr. Vinícius Pedrazzi

Faculdade de Odontologia de Ribeirão Preto - USP

Departamento de Materiais Dentários e Prótese

Av. Café S/N, Ribeirão Preto, SP,

BRASIL

Phone: +55-16-36024008 Fax: +55-16-36330999

E-mail: pedrazzi@forp.usp.br

Received: 23-09-2008

Accepted: 18-11-2008 